\title{
THE INFLUENCE OF EXPERIENTIAL MARKETING ON CUSTOMER SATISFACTION AND LOYALTY OF CORNER COFFEE SHOP IN LANGSA
}

T Maureza Arismunandar*1, Hartoyo*), and Diah Krisnatuti**)

\author{
*) School of Business, IPB University \\ Jl. Raya Pajajaran Bogor 16151 \\ **) Department of Family and Consumer Sciences, Faculty of Human Ecology, IPB University \\ Jl. Lingkar Akademik, Dramaga, Bogor 16680
}

\begin{abstract}
The level of coffee consumption is on a raging level, making the coffee shop business is also increasingly emerging in the form of both local coffee shops and international coffee shops. Coffee Corner is the first coffee shop in Langsa city that combines traditional and modern aspects in its presentation. To ensure business continuity, Kedai Coffee Corner has to create a strategy so that it can boost their customer satisfaction and loyalty by providing experience that can be formed through five dimensions of sense, feel, think, act and relate. This study aims to analyze the influence of experiential marketing on customer satisfaction and loyalty. Corner coffee shop customers of which criteria is above than 17 years old and willing to be respondents are taken and as many as 180 respondents are selected using accidental sampling technique, then the respondents fill out a questionnaire that contains a statement about the variables studied so that the data obtained will then be processed using Structural Equation Modeling (SEM). The result of the research shows that experiential marketing has a significant effect towards customer satisfaction and loyalty either directly or indirectly. Experiential marketing is reflected by two dimensions that have the greatest contribution and those are sense and relate. Better quality and aroma of the coffee as well as superiority in fragrant than other coffee shops, is the indicator that contributes the most to the sensory dimension. An excellent coffee image and quality of the presentation are the indicators that contribute the most to the relative dimension.
\end{abstract}

Keywords: experiential marketing, SEM, corner coffee, sense dimension, relative dimension

\begin{abstract}
Abstrak: Tingkat konsumsi kopi yang semakin meningkat, menjadikan bisnis kedai kopi juga semakin banyak bermunculan baik kedai kopi lokal maupun kedai kopi asing. Kedai Coffee Corner adalah kedai kopi pertama di kota Langsa yang menggabungkan aspek tradisional dan modern dalam penyajiannya. Untuk memastikan keberlanjutan usaha, kedai Corner coffee harus menciptakan strategi sehingga dapat meningkatkan kepuasan dan loyalitas konsumen dengan memberikan experience yang dapat dibentuk melalui lima dimensi yaitu sense, feel, think, act dan relate. Penelitian ini bertujuan untuk menganalisis pengaruh dari experiental marketing terhadap kepuasan dan loyalitas pada konsumen. Konsumen kedai Corner coffee yang memiliki kriteria yaitu berumur lebih dari 17 tahun dan bersedia menjadi responden diambil sebanyak 180 responden yang dipilih menggunakan teknik accidental samplin, kemudian responden mengisi kuisioner yang berisikan pernyataan tentang variabel yang diteliti sehingga data yang diperoleh kemudian diolah menggunakan Structural Equation Modelling (SEM). Hasil penelitian menunjukkan bahwa experiential marketing berpengaruh signifikan terhadap kepuasan dan loyalitas konsumen baik secara langsung maupun secara tidak langsung. Experiential marketing dicerminkan oleh dua dimensi yang memiliki kotribusi terbesar yaitu sense dan relate. Kualitas dan aroma kopi yang lebih baik dan lebih wangi dibandingkan kedai kopi lain merupakan indikator yang berkotribusi paling besar terhadap dimensi sense. Citra kopi yang bagus dan penyajian yang berkualitas merupakan indikator yang berkontribusi paling besar terhadap dimensi relate.
\end{abstract}

Kata kunci: experiential marketing, SEM, corner coffee, dimensi sense, dimensi relate

\footnotetext{
${ }^{1}$ Corresponding author:

Email: tmaureza10@gmail.com
} 


\section{INTRODUCTION}

The increasing level of coffee consumption in Indonesia has made the coffee shop business progressively emerging in the form of local coffee shops and foreign/ international outlets (USDA, 2015). Holbrook (2000) argues that today's business world is entering a new era called "experience marketing". Pine and Gilmore (1999) explain when consumers buy an experience, and then the consumer pays to spend time for an exciting experience and an unforgettable one, causing a sense of satisfaction. According to Schmitt (1999), experiential marketing is formed by five elements: Sense, Feel, Think, Act and Relate those will create a perception or experience in the eyes of consumers. The sense dimension aims to touch the emotions of the consumer through the experience that can be obtained through the five senses (eyes, ears, nose, tongue, and skin. The feel dimension aims to contact through the consumer experience starting with their mood either if that's happy, sad, joy or sorrow. The think dimension is the type of experience that aims to create cognitive that will invite consumers to think creatively. The act dimension aims to create an experience with consumers that are related to behavior, lifestyle and interaction with others. The relate dimension incorporates aspects of sense, feel, think, and act to create a community within the customers with communication so that customers feel accepted in their environment.

Langsa is one of the few cities in Aceh with many coffee shops, ranging from traditional to ones with modern facilities such as internet; television and music are added for the sake of the comfort of coffee lovers. One of the first coffee shops that provide a modern twist is Corner coffee which was established in 2010. To survive in the business world, Corner coffee must be able to provide the best service in accordance with the consumer expectations to increase customer satisfaction and loyalty.

Experiential marketing is a marketing strategy that is utilized to influence one's emotions by creating an experience that consumers can feel when consuming a product or service that leads to a sense of satisfaction. Marknesis (2009) suggests that satisfied consumers tend to be loyal to the same products and producers, in contrast consumers who are not satisfied will find a new product or service that is more satisfying for them.
The high consumer demand for ready-to-eat products and the culture of enjoying coffee that has become a lifestyle for the people of Aceh has become one of the reasons coffee shop business opportunities continue to progressively increase. This can be seen by the jolting number of new coffee shops emerging in the city of Langsa, to this day there are more than 17 names of new coffee shops and certainly are competitor for Corner coffee shop.

A study on experiential marketing in coffee shops and cafes has been often found in Indonesia, one of which, was conducted by Vernawati and Kartikasari (2015) who stated that experiential marketing has a significant effect on customer satisfaction. Hadiwidjaja and Dharmayanti (2014)'s study also said that the five dimensions of experiential marketing have a significant influence on satisfaction and only the dimensions of the sense, think and relate that significantly affect customer loyalty. Ekoputra (2017) said experiential marketing has a significant influence on satisfaction but no significant effect on loyalty. Noegroho et al. (2013) from the results of path analysis shows that the variables of experiential marketing and brand trust have a significant effect on the customer loyalty variable. Dimyati (2014) stated that experiential marketing has a significant effect on patient satisfaction but insignificant to patient loyalty. Jatniko and Andharini (2012) found experiential marketing has a significant positive effect on customer loyalty. This research aims to analyze the influence of experiential marketing on customer satisfaction and loyalty.

In Figure 1 it is stated that Corner coffee shop turnover in 2016 has decreased significantly, so if it continues to happen, it will threaten the sustainability of the business. Therefore it is important for Corner coffee to quickly determine the right marketing strategy so that consumers do not turn to their competitors. To formulate the right marketing strategy it is crucial to know in advance the experience felt by consumers whether it is able to cause satisfaction and loyalty to Corner coffee consumers. This study would like to see the application of experiential marketing that has been applied by the Corner coffee shop and whether it can provide satisfaction and affected into loyalty to the consumers therefore as a pioneer of the first coffee shop (in Langsa) does not lose their customers. 


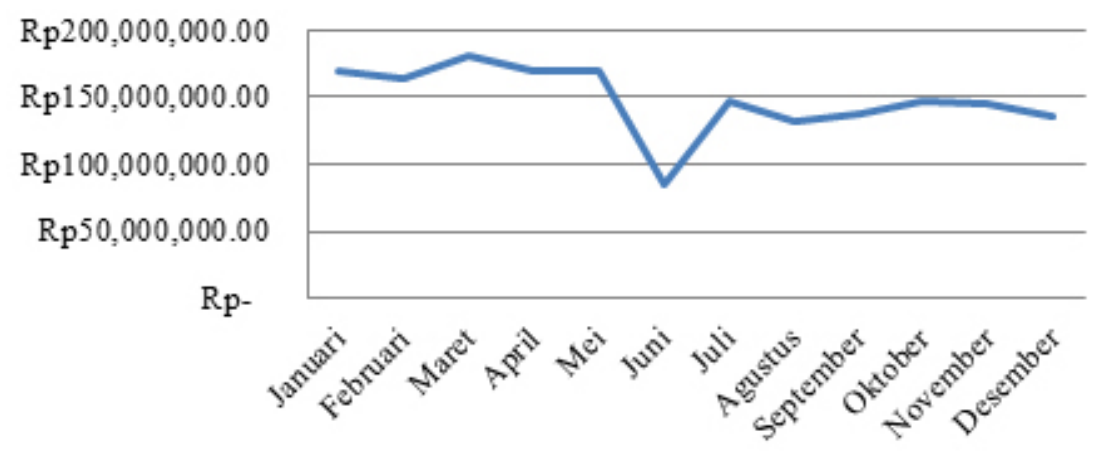

Figure 1. Corner coffee shop turnover in 2016

\section{METHODS}

This research is a descriptive research and made use of questionnaires filled directly by respondents. Object of this research are Coffee Corner, a coffee shop located at Ahmad Yani Street, Langsa City, Aceh, at September 2017. Population in this study is coffee consumers at Langsa City, with consumers of Coffee Corner as the sample. Sample size of 180 respondents were taken based on rule of thumb, and samples were taken by accidental sampling technique, which is a sampling technique based on coincidence that anyone who happens to meet with the researcher and considered a match to the criteria is made to be respondents. The respondent's criteria itself is over 17 years old and willing to be a respondent.

Data were analyzed using Structural Equation Modeling (SEM). SEM is a multivariate technique that combines multiple regression and factor analysis to simultaneously simulate a series of dependence relationships (Hair et al. 1998). SEM was used in this study due to its ability to explore entire relation between each dimensions and variables.

Experiential marketing consists of five dimensions, which are sense, feel, think, act, and relate, and then study its relation to customer satisfaction. Customer satisfaction is reflected by three indicators, which are perceived product quality, perceived service quality, and perceived price fairness. Then, customer satisfaction well by observed its correlation to consumers' loyalty which is reflected by four indicators, which are committed to the brand, repurchase, recommending the product, and willing to pay more. Framework of this research can be seen on Figure 2.

\section{RESULTS}

The results showed that respondents that are in the premises of this research which is Corner coffee shop is male and is equal to $88 \%$ or as many as 159 respondents and female consumers are only by $12 \%$ or as many as 21 respondents. Age of respondents ranged between 18-30 years old has the largest proportion of $78 \%$ or as many as 141 people respondents, while ages over 30 years old and above is by $22 \%$ or as many as 39 respondents. Coffee enthusiasts are dominated by young people who have a hobby of relaxing both alone and with friends.

There are various types of respondent's work, such as $30 \%$ or 54 respondents, $24 \%$ or 43 respondents, $22 \%$ private employees or 39 respondents, civil servants $16 \%$ or 29 respondents, and employees of BUMN 3\% or as many as 5 respondents. The largest proportion is $47 \%$ or as many as 85 respondents have income of $\leq$ Rp2,500,000 per month. Then by $43 \%$ or as many as 79 respondents have income ranging from $\mathrm{Rp} 2,500,001-$ Rp5,000,000.

In general, respondents who visits Corner coffee shop between $2-3$ times a weeks are equal to $38 \%$ or as many as 69 respondents, both on weekdays and weekends. On weekdays the periods are specified again into three categories which are before going to work, on break time and after work. Respondents who chose at after work period to enjoy their coffee is about $56 \%$ or as many as 29 respondents, following at break time in $40 \%$ or as many as 21 respondents. On weekends the periods are classified into the morning, afternoon, evening and at night. As many as $54 \%$ or 69 respondents visited Corner coffee shop at night and by $34 \%$ or as many as 43 respondents visited Corner coffee shop in the evening. 


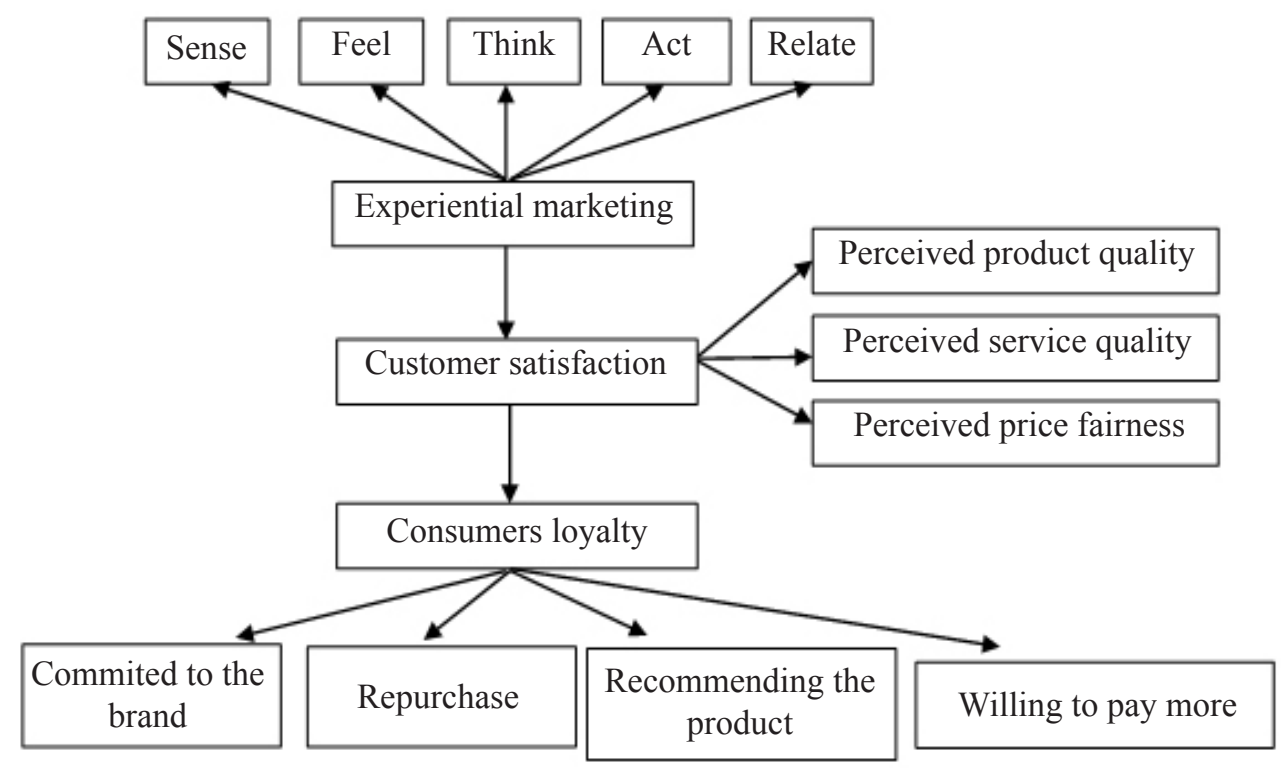

Figure 2. Research framework

Most respondents of which are as many as 164 people or $91 \%$ are more often enjoy coffee with a companion. Activities made by the majority of respondents during their time in the coffee shop that is equal to $63 \%$ or as many as 114 respondents is doing casual conversation with their acquaintance. The most ordered menu at Corner coffee shop is black coffee with a percentage of $41 \%$ or as stated by as many as 73 respondents. Expenditure spent by respondents to enjoy coffee ranges from $\mathrm{Rp} 10,000$ to $\mathrm{Rp} 15,000$ per day with a percentage of $53 \%$ or as many as 96 respondents.

The coffee shop business is one of the perfect business competition of which means there are many similar businesses with other variations so that coffee connoisseurs have many choices. There are 17 names of other coffee shops, in addition to Corner coffee shops that have been visited by respondents; of those are Pos Kopi by $42 \%$ or as many as 70 respondents and Ibam's coffee shop by $22 \%$ or as many as 36 respondents. Not all respondents have tried other coffee shops, there are also respondents who have never tried other coffee shops and say they want to try Ibam's coffee shop for $64 \%$ or as many as 9 respondents and 29\% Pos Kopi for 4 respondents. As many as $37 \%$ or 68 respondents argued that they tried another coffee shop because they were invited by their friend. Other respondents' or as many as 50 people or $28 \%$ curious to try the taste of other coffee elsewhere and by $26 \%$ or as many as 46 respondents chose to try for a new place.

\section{Overall Variable Model}

Experiential marketing

Experiential marketing is a form of marketing development to build relationships with consumers based on experience that can be formed through the five dimensions of sense, feel, think, act, and relate to products or services consumed (Schmitt, 1999).

Consumers Satisfaction

Consumer satisfaction is a behavioral, judgement and emotional response addressed by the consumer after the purchase or consumption process and is derived from the comparison of their impression of the actual performance of a product and its expectations and evaluation of the experience after consuming a product or service (Azizah and Widyastuti, 2013).

Loyalty

Maintaining customers means improving financial performance and preserving the viability of the company, so if the company has loyal customers, it will be a very valuable asset for the company (Harzalia, 2016).

Figure 3 shows that all the variables have met the Standardize loading factor value $\geq 0.5$ which means that the whole variable has a decent validity value, and also has significant relation seen from the star 
sign showing the t-value value $\geq 1.96$. Experiential marketing variable has five dimensions of which is sense, feel, think, and act and relate and bear different values of contribution. There are two dimensions that have the highest contribution value which is the sense dimension with 0.97 and relate with 0.93 . Satisfaction is represented by PPF indicator which has the biggest contribution in 0.88 and variable loyalty represented by indicator of PULK which have biggest contribution that is 0.94 .

The dimension of sense marketing is intended to provide experience to consumers by affecting the emotions that are relieved through the five senses. The sense dimension has the effect with the highest value of 0.97. The sense dimension is reflected by three indicators but there are only two indicators that have an effect with almost the same value and reflect the sense dimensions of sense 1 and sense 2 . Sense 1 says that the quality of coffee in Corner coffee stores is better than other coffee shops. As many as $60 \%$ or as many as 108 respondents are agree with the statement in sense 1 . Sense 2 said that the aroma of coffee owned Corner coffee shop is more fragrant aroma than other coffee shops can be seen in Table 1 of $58 \%$ or as many as 104 respondents agreed with the statement in sense 2 . The sense 3 indicator has a small contribution value to the sense dimension. Only $30 \%$ or as many as 54 respondents who agree that Corner coffee shop has an interesting design.

In Table 2 it can be seen that the relate dimension has an influence with the second highest value after the sense dimension with a value of 0.93 . Relate dimension aims to form a consumer community with communication so that consumers are able to have relationships with other people and other social groups. Relate dimensions are reflected by three indicators but there are only two indicators that have an effect with values that are almost equal in magnitude and reflect the relate dimension which are relate 3 and relate 2 . Relate 3 stated that enjoying coffee at Corner coffee shows that the consumer has a good taste in coffee. It is approved by $55 \%$ or as many as 99 respondents. Relate 2 says that the servers at Corner coffee shop always interact with consumers and $56 \%$ or as many as 100 respondents agree with the statement. Consumers do not always interact with other fellow consumers at Corner coffee shop therefore the resulting value is smaller than two other indicators and only $48 \%$ or as many as 86 respondents who agree with the statement of relate 1 .

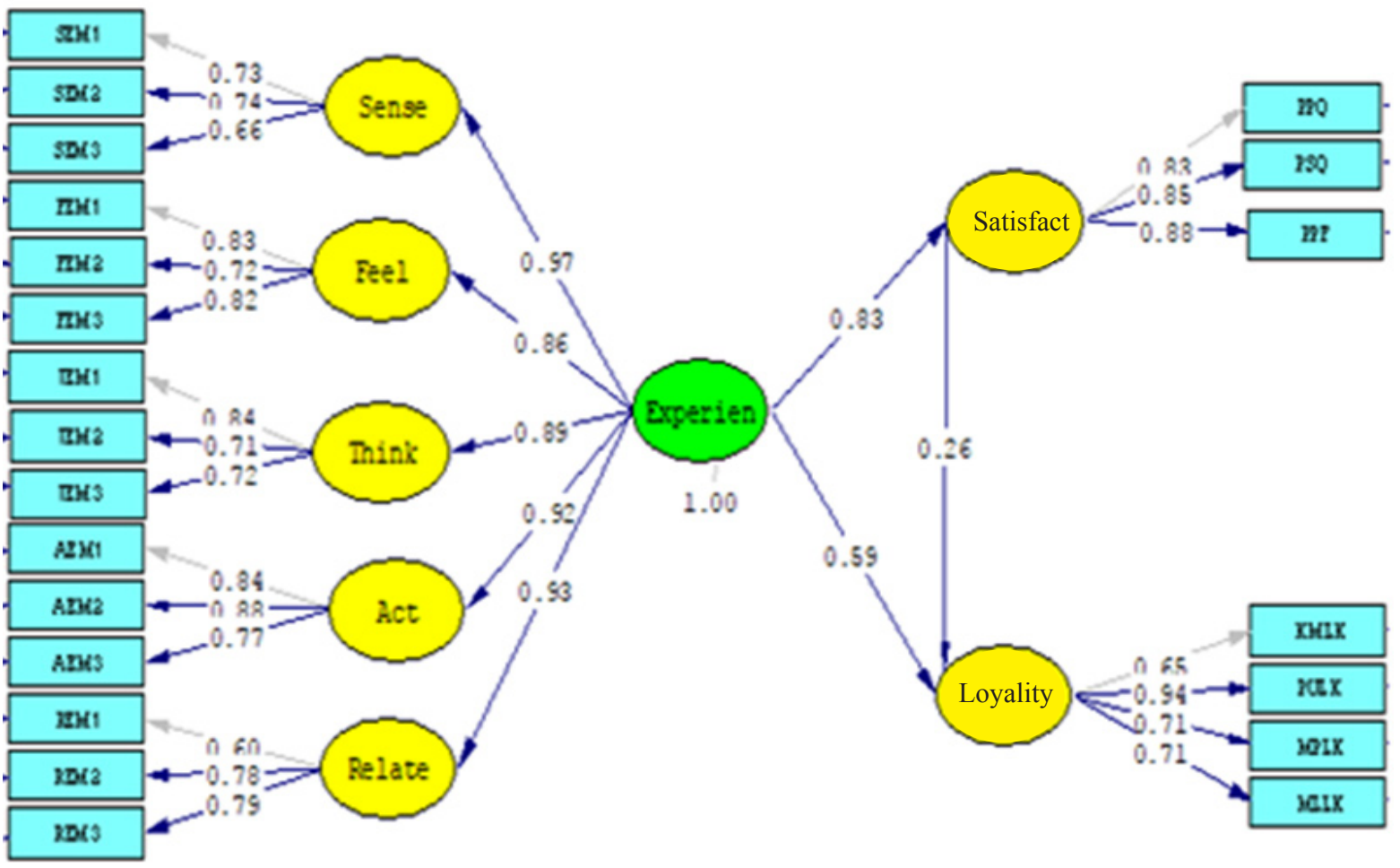

Figure 3. Variable model (standardize loading factor) 
Satisfaction is what every business wants to achieve in the coffee shop business. In Table 3, it is known that the satisfaction variable has three indicators that reflect the variables of which are perceived product quality, perceived service quality, and perceived price fairness. All three indicators have different contribution values. Perceived price fairness indicator is an indicator with the highest contribution value of 0.88 , meaning that the majority of respondents are overall satisfied with the products or services provided by the Corner coffee shop.

Satisfaction assessed in this case is not only a matter of price but overall means all that is sacrificed by the consumer to get the product or service in accordance with the expectations of both consumers in terms of time, price, and distance traveled by consumers to get the products and services. Table 3 also shows that respondents who are satisfied with the statement of perceived price fairness are $67 \%$ or as many as 120 respondents. From Table 3 it is known that only $62 \%$ or as many as 111 respondents agree with the statement from Perceived Service Quality that the service at Corner coffee shop has been as expected. The value is smaller than the other two indicators, which means there are still consumers who are not satisfied with the services provided by Corner coffee shop.

Consumers who are satisfied not necessarily loyal but loyal customers are certainly satisfied with a product or service. In Table 4 above it can be seen that in the loyalty variable there are four indicators and those are brand commitment (KMLK), repurchase (PULK), recommendation of the product (MPLK), and paying more (MLLK).

Indicator that reflects the loyalty variable is PULK with SLF value equal to 0.94. PULK indicator said that the majority of respondents answered that they do interested in repurchasing by always spend time to enjoy coffee at Corner coffee and equal to $51 \%$ or as many as 92 respondents agree with PULK statement on consumer loyalty can be seen in table 4 above. There are two statements that respondents do not agree those two are KMLK and MLLK. KMLK indicator said that the consumers do not want to try another coffee shop by $28 \%$ or as many as 50 respondents agreed and vice versa $72 \%$ or as many as 130 people said disagree. One of the causes is the number of similar coffee shops that have different variations and consumers today are easily bored with one place, very few consumers who remain loyal and do not want to try a coffee shop other than Corner coffee shop.

MLLK indicator said that consumers will still be purchasing at Corner coffee shop even if the price increases by $40 \%$ or as many as 72 respondents agree and on the contrary $60 \%$ or as many as 108 people say disagree. If Corner coffee stores raise prices, then consumers will move to another coffee shop so then will not get loyal customers.

Table 1. Sense indicator

\begin{tabular}{llcc}
\hline Indicator & Statement & Agree (\%) & Disagree (\%) \\
\hline Sense 1 & Corner coffee shop has a better coffee quality than other coffee shop & 60 & 40 \\
Sense 2 & Corner coffee's coffee has more fragrant & 58 & 42 \\
Sense 3 & Corner coffee has an interesting design & 30 & 70 \\
\hline
\end{tabular}

Table 2. Relate indicator

\begin{tabular}{llcc}
\hline Indicator & Statement & Agree (\%) & Disagree (\%) \\
\hline Relate 1 & Consumers interact with new people who also enjoys coffee & 48 & 52 \\
Relate 2 & The servers always interact with the consumer & 56 & 44 \\
Relate 3 & The coffee at corner coffee has a nice coffee image & 55 & 46 \\
\hline
\end{tabular}

Table 3. Satisfaction indicator

\begin{tabular}{llcc}
\hline Indicator & Statement & Agree (\%) & Disagree (\%) \\
\hline Perceived product quality & Quality of coffee fit with consumers expectation & 67 & 33 \\
Perceived service quality & Service in Corner coffee fit with consumers expectation & 62 & 38 \\
\hline
\end{tabular}


Table 4. Loyalty indicator

\begin{tabular}{llcc}
\hline Indicator & Statement & Agree (\%) & Disagree (\%) \\
\hline Brand commitment (KMLK) & Consumers do not want to try another coffee shop & 28 & 72 \\
Repurchase (PULK) & Consumers always enjoy coffee at Corner coffee & 51 & 49 \\
$\begin{array}{l}\text { Recommendation of the product } \\
\text { (MPLK) }\end{array}$ & Consumers talk positively about Corner coffee & 59 & 41 \\
Paying more (MLLK) & Consumers will still be purchasing at Corner coffee & 40 & 60 \\
& shop even if the price increased & & \\
\hline
\end{tabular}

In Table 5, the usage of RMSEA criteria resulted in a value of $0.005 \leq 0.08$ which means that the resulting model is good (good fit). The use of other goodness of fit criteria is NFI, CFI, NNFI, IFI, and RFI resulting in value $>0.90$ means that the model is good (good fit). While for AGFI and GFI has a value of $<0.90$, but it is still above 0.80 indicating that the criteria is passable as well as the other criteria of goodness of fit measurements the RMR yield value in $\leq 0.1$ which means the model is $\operatorname{good}(\operatorname{good}$ fit). From several criteria that resulted in the conclusion of goodness of fit model, hypothesis testing can be done and it also indicates that the result of the questionnaire has been able to answer the theory.

The analysis of casual relation is done to examine the influence between variables. The testing process is done by testing the value of $\mathrm{t}$-value whether it is greater than 2.46 or at level $1 \%$ and greater than 1.96 or at $5 \%$ level. Table 6 shows the value of $\mathrm{t}$-value and path coefficients that explain the influence of relationships between variables and to determine the direction of influence between variables in this research.

Experiential marketing and satisfaction have a significant effect of 0.83 . Experience provided by Corner coffee shop able to make the consumer feel satisfied and if the experiential marketing improve then it will directly also increase the satisfaction of the consumers. This is in line with Venkat's research (2007) which proves that experience has a significant influence on customer satisfaction. Experiential marketing is also directly from loyalty of 0.59 . Experiential marketing provided by Corner coffee shop has a positive influence on loyalty and if experiential marketing improved then consumer loyalty will increase. In line with the research of Elvina (2011) which says experiential marketing has a significant effect on customer loyalty means hypothesis 2 is accepted. Research from Putri and Astuti (2010) also explains that experiential marketing has a positive influence on loyalty.

The influence of satisfaction on loyalty also has a significant effect with 0.26 , meaning satisfaction is a major factor in shaping consumer loyalty and this is in line with research Indriyani et al. (2016) who says satisfaction has a significant effect on visitor's loyalty and for those hypothesis 3 is acceptable. Experiential marketing also has a significant effect on loyalty through satisfaction mediation of 0.22 , this is called indirect influence because it goes through satisfaction mediation. In line with the research of Hadiwidjaja and Dharmayati (2016) experiential marketing has a direct and indirect influence on consumer loyalty and has a significant effect either directly or indirectly.

\section{Managerial Implications}

Results shows that sense and relate are the most important dimension within experiential marketing. Sense reflecting quality and aroma of the coffee and relate reflecting communication within Coffee Corner, be it employees-customers communication, or communication among themselves. This suggest that Coffee Corner should keep authenticity and quality of coffee beans used and maintain and improve barista ability to ensure they could serve the best coffee using traditional Aceh "pulled" coffee making. Communication inside Coffee Corner is also suggested to be improved. Coffee Corner must "communicate" further so that the customers could feel deeper relation, such as by providing suggestion box, providing live music, or even holding periodic event. 
Table 5. Compatibility result model

\begin{tabular}{lccc}
\hline Goodness-of-Fit & Cut-off-Value & Result & Description \\
\hline RMR (Root Mean Square Residual) & $\leq 0.1$ & 0.045 & Good fit \\
RMSEA (Root Mean square Error of Approximation) & $\leq 0.08$ & 0.056 & Good fit \\
GFI (Goodness of Fit) & $\geq 0.90$ & 0.87 & Marginal fit \\
Adjusted Goodness of Fit Index (AGFI) & $\geq 0.90$ & 0.83 & Marginal fit \\
CFI (Comparative Fit Index) & $\geq 0.90$ & 0.99 & Good fit \\
Normed Fit Index (NFI) & $\geq 0.90$ & 0.97 & Good fit \\
Relative Fit Index (RFI) & $\geq 0.90$ & 0.96 & Good fit \\
Non-Normed Fit Index (NNFI) & $\geq 0.90$ & 0.98 & Good fit \\
Incremental Fit Index (IFI) & $\geq 0.90$ & 0.99 & Good fit \\
\hline
\end{tabular}

This research also suggests STP strategy based on the results. Sample demography shows that coffee consumption are evenly spread within all income groups, which probably caused by culture. Therefore, segment wise, Coffee Corner should provide its services and products to all groups. Target wise, Coffee Corner should aim for students and entrepreneur, since occupation demography shows that these groups visit coffee shops more. As for positioning, Coffee Corner is suggested to be youth friendly. It is decorating with cozier furniture and providing affordable price range products or via discount promotion to further cement their place in Student and youth mindset.

\section{CONCLUSIONS AND RECOMMENDATIONS}

\section{Conclusions}

The application of experiential marketing by Corner coffee shop has been excellent and able to be felt by the consumers. There are two dimensions of experiential marketing that has a low value and that is the feel and think dimension. The influence of experiential marketing on customer satisfaction has a significant and positive effect, meaning that the application of experiential marketing done by Corner coffee shop can make consumers feel directly satisfied. Experiential marketing to consumer loyalty has a significant influence either directly or indirectly through the variable of customer satisfaction, it says that the application of good experiential marketing can directly create loyal customers both in terms of the coffee quality and comfort of the place.

The influence of customer satisfaction on customer loyalty in the Corner coffee shop is also significant but the resulting value is very low. This is due to the number of similar coffee shops that have sprung up. There are 17 similar coffee shops and are competitors for Corner coffee shop and also consumers today are limited to drinking coffee alone regardless of the quality and aroma of the coffee. The value of the influence satisfaction on consumer loyalty is considered low which can also be due to the fact of the low number new consumers who are loyal to Corner coffee means only old consumers who are remain loyal to Corner coffee resulting in a fairly low value.

Of thefive dimensions that reflectexperiential marketing, there are two dimensions that contribute to the greatest value of which are the sense and relate dimension. The Sense dimension explained that the Corner coffee shop has a better quality of coffee and coffee aroma than any other coffee shop. The Relate dimension stated that the servers at the Corner coffee shop are always interacting with consumers so that consumers are comfortable with the hospitality provided and the majority of consumers say that enjoying coffee at Corner coffee shop shows that consumers have a good taste in coffee.

\section{Recommendations}

This research has the limitations of just surveying at a coffee shop only and not comparing with other competitors, also the level of satisfaction and loyalty reached in this research has not been able to describe how loyal consumers to the Corner coffee shop. So it is advisable for further research with similar topics to be able to add more variables and broader scope of research or can also compare the coffee shop with other coffee shops to make the research on experiential marketing more interesting. Further research is also expected to be able to deepen the dimension of experiential marketing to know the advantages and disadvantages of dimensions. 


\section{REFERENCES}

Azizah, Widyastuti A. 2013. Hubungan antara kepuasan konsumen dengan loyalitas merek pada pengguna kartu prabayar simpati. Jurnal Psikologi 9(1): 1-8.

Dimyati M. 2014. Peranan experiential marketing dan kepuasan pasien dalam menciptakan loyalitas pasien rumah sakit Fatimah banyuwangi. Jurnal Universitas Jember 13 (2): 1-18.

Elvina. 2011. Hubungan gangguan fungsi kognitif dengan hipertensi ditinjau dari Aspek IL-6 dan TLF-ALFA [thesis]. Padang: UNPA.

Ekoputra. 2018. Pengaruh experiential marketing terhadap kepuasan dan loyalitas pelanggan restoran 150 Eatery di Bogor [thesis]. Bogor: Institut Pertanian Bogor.

Hadiwidjaja RS, Dharmayanti D. 2016. Analisis hubungan experiential marketing, kepuasan pelanggan, loyalitas pelanggan Starbucks Coffee di Surabaya Town Square. Jurnal Manajemen Pemasaran 2(2): 1-11.

Harzalia H. 2016. Pengaruh strategi pemasaran dan experiential marketing terhadap loyalitas pelanggan terash mini café Sungailiat Kabupaten Bangka [skripsi]. Bangka: Universitas Bangka Belitung.

Holbrook MB. 2000. The millenial consumer in the texts of our times: experience and entertainment. Journal of Macromarketing 20(2): 178-192. https://doi.org/10.1177/0276146700202008.

Indriani AR, Wilopo, Pangestuti E. 2016. pengaruh experimential marketing terhadap kepuasan dan loyalitas pengunjung (Studi pada Jawa Timur Park 2 Kota Batu). Jurnal Administrasi Bisnis 37(2): 113-120.

Jatmiko, Andharini. 2012. Analisis experiential marketing dan loyalitas pelanggan jasa wisata (Studi pada taman rekreasi sengkaling malang).
Jurnal Manajemen dan Kewirausahaan 14(2): 128-137. https://doi.org/10.9744/jmk.14.2.128137.

Marknesis. 2009. Customer Satisfaction and Beyond. Yogyakarta: Marknesis.

Noegroho OA, Suharyono, dan Kumadji S. 2013. Pengaruh experiential marketing dan brand trust terhadap kepuasan pelanggan dan loyalitas pelanggan (survei pada pelanggan kfc cabang kawi malang). Jurnal Administrasi Bisnis 6(2): $1-7$.

Pine BJ,Gilmore JH. 1999. The Experience Economy. Boston: Harvad Business Scholl Press

Putri YA, Astuti SRT. 2010. Analisis pengaruh experiental marketing terhadap loyalitas pelanggan hotel X semarang. Jurnal Universitas Diponegoro 12(2): 191-195.

Schmitt BH. 1999. Experiental Marketing: How To Get Customers Tosense, Feel, Think, Act, Relate To Your Company And Brands. New York: The Free Press.

Tse W. 1988. Models of consumer satisfaction formation: an extension. Journal of Marketing Research 25(2): 204-212. https://doi. org/10.1177/002224378802500209.

[USDA] United State Departemen of Agriculture. 2015. Global agricultural information report: Indonesia coffe semi-annual report 2015. Jakarta: FAS USDA.

Vernawati DD dan Kartikasari D. 2015. Pengaruh experiental marketing terhadap kepuasan pelanggan di heritage coffee batam. Proceeding "3"Applied Business and Engineering Conference 127: $1-7$.

Venkat R. 2007. Impact of customer experience on satisfaction, brand image and loyalty: a study in a business-to-business context. Journal of Marketing 28(3): 101-114 